Acta vet. scand. $1968,9,242-252$.

From the Department of Reproductive Physiology and Pathology,

Veterinary College of Norway, Oslo.

\title{
STUDIES ON REPRODUCTION IN THE GOAT
}

\section{THE GENITAL ORGANS OF THE PREGNANT GOAT}

By

Olav Lyngset

Up to the present time few attempts have been made to describe the sex organs of the pregnant goat. In India Taneja (1959) and Basu et al. (1961) examined 161 and 74 organs respectively from pregnant goats. Basu et al. studied the functional activity of the ovaries and the uterine horns. Taneja was especially interested in "ovum loss" of which he found two cases in his material.

In the autumn of 1964 a study of the sex organs of goats, using slaughterhouse material, was started. The aim of the present study was to obtain a survey of the frequency of pathological changes in the genital tract of the goat in Norway. The study later also included the recording of normal anatomical and physiological conditions. In a previous paper a survey of the results obtained from 221 organs from normal non-pregnant goats was given (Lyngset 1968a).

The following is a summary of the results from the study of a total of 397 organs from pregnant goats. Some of the results have been published in a preliminary report (Lyngset 1966).

\section{MATERIALS AND METHODS}

The collection of the organs is described in detail in an earlier paper (Lyngset 1968a). In Norway the sexual season of the goat extends from the end of June and onwards, and most of the matings take place in the months of July, August and September. The slaughtering season is in the months of October, November and December. Due to the timing of the slaughter season in relation to the mating season a large number of the sex organs 
examined were from pregnant goats. Out of 1020 organs a total of 397 were from animals in different stages of pregnancy. The length of the foetus varied within the range of 1 to $35 \mathrm{~cm}$.

Approximately 270 of the pregnant organs were examined in details. The measurements of the ovaries were carried out as previously described (Lyngset 1968a). The corpora lutea were enucleated, measured and then weighed. The follicles were recorded and measured only when they were prominent on the surface. The length of the foetuses was measured from the forehead to the fixation of the tail or in the smallest foetuses recorded as the total length. The caruncles were counted in a number of cases. They were counted in each horn separately and in the uterine body.

\section{RESULTS}

\section{General observations}

By direct inspection of the uterus pregnancy was relatively easy to diagnose, even at the earliest stages. Only in a couple of cases pregnancy was not observed on inspection. In these cases the foetuses were very small, the amniotic sac measured only about $2 \mathrm{~cm}$ and the amniotic fluid was very sparse. In Fig. 1 an organ in an early stage of pregnancy is shown beside a nonpregnant organ. The pregnant organ in Fig. 1 contains two
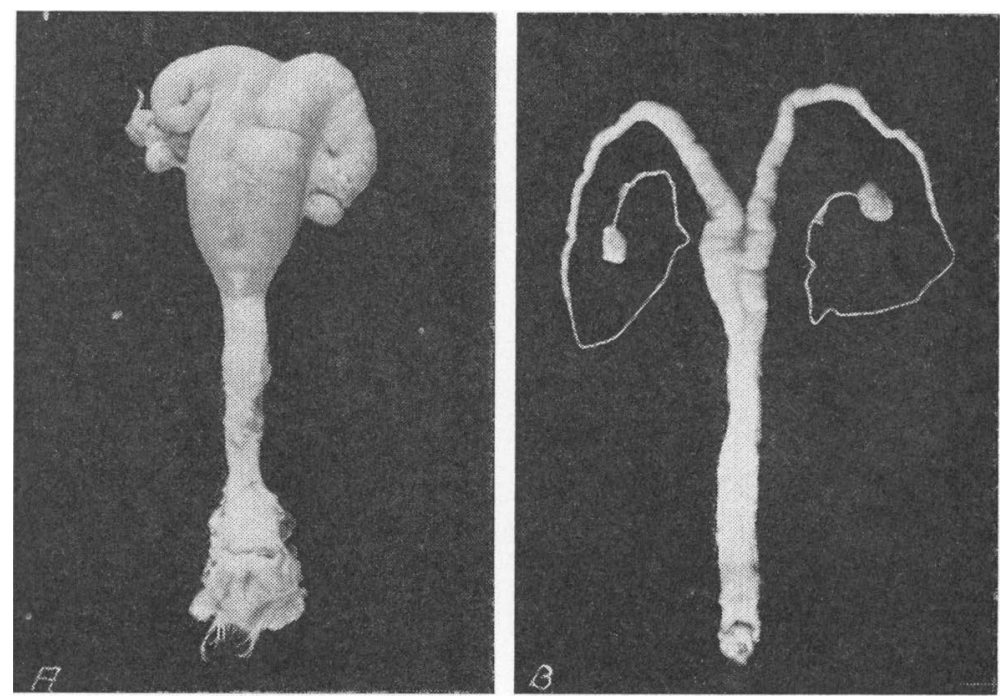

F ig u r e 1. A. The genital organs of a pregnant goat (pregnant with two foetuses). B. The genital organs of a non-pregnant goat. 
foetuses. The increase in volume of the organ is very obvious. The size of the organ and the symmetry of the two uterine horns will naturally vary with the number of foetuses. Richter \& Götze (1960) claim that in a twin pregnancy with one foetus in each uterine horn the uterus is symmetrical. In this material a marked asymmetry of the uterine horns was frequently found even in cases with one foetus in each horn. When such an organ was cut open the foetuses were found to be of equal size and the asymmetry was caused by unequal amounts of amniotic fluid. It must be assumed therefore that the distribution of the amniotic fluid is not exactly the same in both horns at all times during pregnancy.

On cutting open the genital organs some greyish-white, tough mucus is often found in the vagina. The cervix is contracted and closed by a tough mucus plug somewhat more yellowish-brown of colour. In the uterus, the caruncles are found spread over the whole mucous membrane, usually in four rows out to the very tip of the uterine horn. The distribution of the caruncles is usually regular, though an uneven distribution of the caruncles can be seen (Fig. 2). In the uterus on the figure especially the left uterine horn contains few caruncles unevenly distributed.

It is very difficult to decide whether or not all the caruncles are functionally active. In early pregnancy a great deal of the
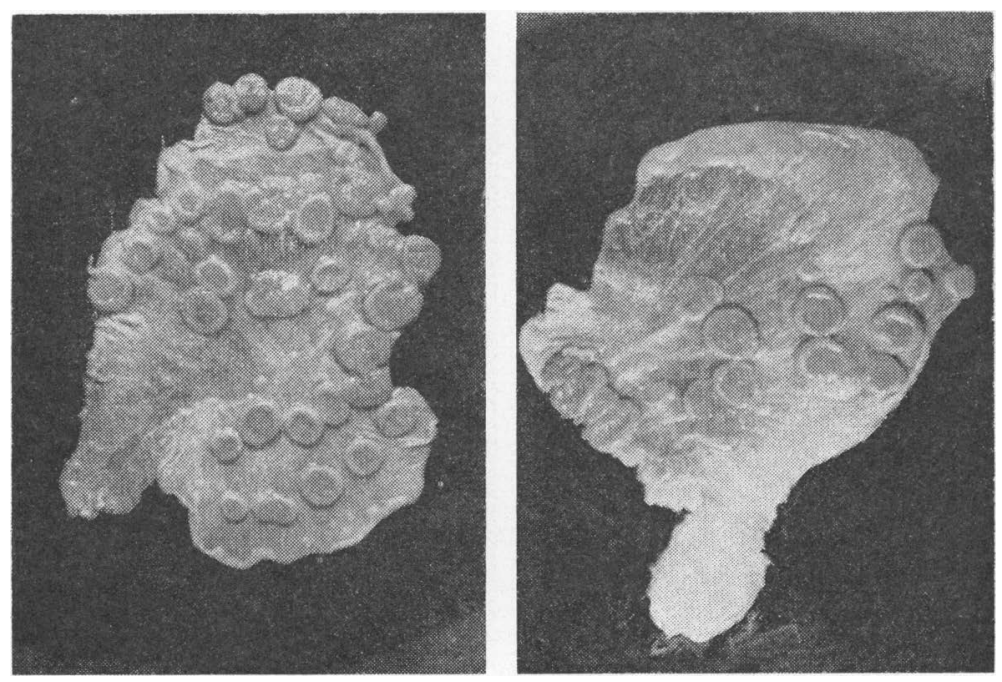

Figure 2. The uterine horns of a goat showing an uneven distribution of the caruncles. 
caruncles do not take part in the placentation. This can be observed in the tip of the uterine horns especially in the nonpregnant horn in single pregnancies. Even in advanced pregnancy more caruncles are present than those actively taking part in the placentation.

The caruncles in the goat have a saucer-like shape, and the cotyledons are fastened in the formed concavity. They are usually round or somewhat elongated in shape with a diameter of up to $6-8 \mathrm{~cm}$.

In the ovaries, in addition to the corpora lutea of pregnancy, one or more follicles are often found prominent on the surface. These follicles approach the size of a mature Graafian follicle (Fig. 3). The follicles can be found both in the ovary where ovulation has taken place and in the opposite ovary. In one case a cyst was also found in one ovary in addition to a corpus luteum of pregnancy. The diameter of the cyst was as great as that of the corpus luteum.

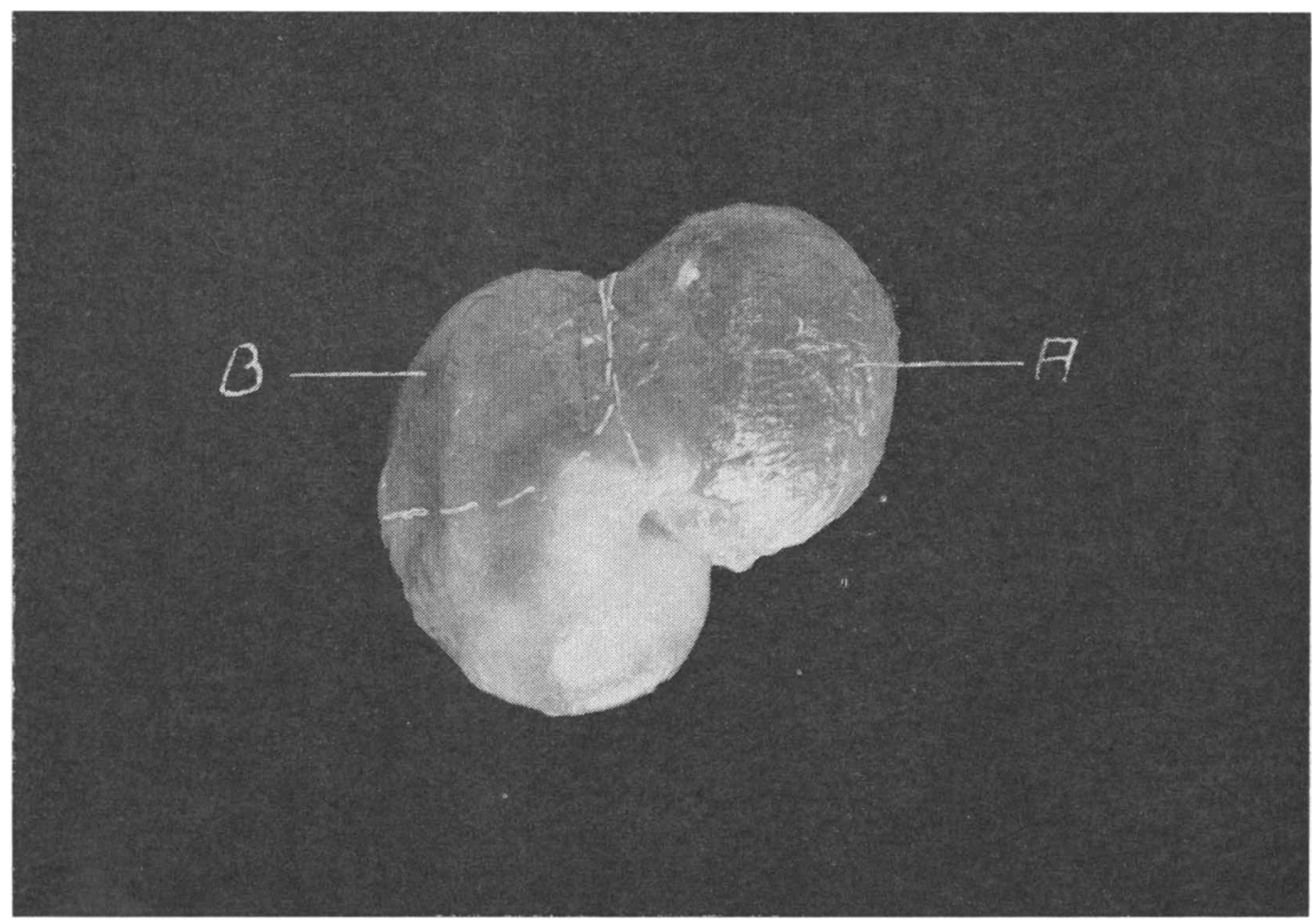

Figure 3. The ovary of a pregnant goat. A. Corpus luteum graviditatis. B. Follicle. 


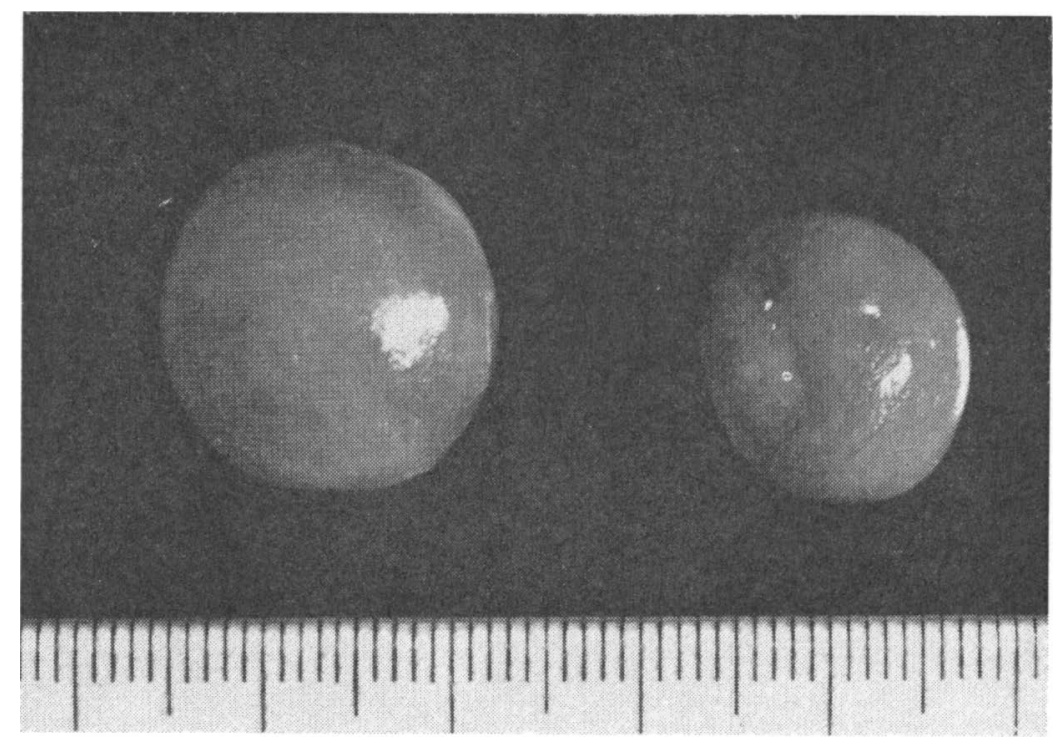

F i g u r e 4ariation in the size of the corpus luteum.

The morphology of the ovary was described previously (Lyngset 1968a). The presence of one or more corpora lutea in the ovary will naturally increase its volume. The corpus luteum of pregnancy does not protrude on the surface of the ovary. The corpus luteum can vary somewhat in size which is shown in Fig. 4. Both of the corpora lutea in the figure are from single pregnancies where only one corpus luteum was formed.

\section{Results of the measurements}

In some of the material (about 270 organs) measurements of the length, breadth, thickness and weight of the ovaries were undertaken. The means of the measurements are recorded in Table 1. The weight of the right and left ovary is $2.34 \mathrm{~g}$ and $2.15 \mathrm{~g}$ respectively. Table 1 also shows an equal number of caruncles in the two uterine horns, 61.3 caruncles in the right and 60.7 caruncles in the left uterine horn.

The variation in the size of the ovaries in relation to the number of corpora lutea is shown in Table 2. There is an increase in the size of the ovaries with increasing number of corpora lutea.

Table 3 shows the diameter and weight of the corpus luteum. The diameter of the corpus luteum is $1.42 \mathrm{~cm}$ and $1.33 \mathrm{~cm}$ respectively whether there is one or two corpora lutea in the same 
Table 1. Biometrical observations on the genital organs of the pregnant goat $(\mathrm{cm}, \mathrm{g}$ and numbers).

\begin{tabular}{clccc}
\hline & & $\begin{array}{c}\text { No. of } \\
\text { observ. }\end{array}$ & Mean & s \\
\hline Right ovary & lenght & 269 & 2.28 & 0.35 \\
& width & 269 & 1.72 & 0.31 \\
& depth & 269 & 1.17 & 0.23 \\
Left ovary & weight & 153 & 2.34 & 0.32 \\
& length & 252 & 2.21 & 0.40 \\
& width & 252 & 1.61 & 0.29 \\
Caruncles & depth & 252 & 1.10 & 0.27 \\
" & weight & 144 & 2.15 & 0.28 \\
& right horn & 56 & 61.31 & 3.39 \\
& left horn & 55 & 60.71 & 3.61 \\
& corpus uteri & 40 & 4.71 & 0.28 \\
\hline
\end{tabular}

T a b l e 2. Variation in the size of the ovaries in relation to the number of corpora lutea $(\mathrm{cm}$ and $\mathrm{g})$.

\begin{tabular}{|c|c|c|c|c|c|c|c|}
\hline & & \multicolumn{2}{|c|}{ No c.l. } & \multicolumn{2}{|c|}{1 c.l. } & \multicolumn{2}{|c|}{2 c.l. } \\
\hline & & $\begin{array}{l}\text { No. of } \\
\text { observ. }\end{array}$ & $\begin{array}{l}\text { mean } \\
\text { value }\end{array}$ & $\begin{array}{l}\text { No. of } \\
\text { observ. }\end{array}$ & $\begin{array}{l}\text { mean } \\
\text { value }\end{array}$ & $\begin{array}{l}\text { No. of } \\
\text { observ. }\end{array}$ & $\begin{array}{l}\text { mean } \\
\text { value }\end{array}$ \\
\hline \multirow[t]{4}{*}{ Right ovary } & length & 75 & 2.04 & 125 & 2.28 & 64 & 2.50 \\
\hline & width & 75 & 1.50 & 125 & 1.74 & 64 & 1.90 \\
\hline & depth & 75 & 0.98 & 125 & 1.20 & 64 & 1.30 \\
\hline & weight & 53 & 1.59 & 62 & 1.35 & 37 & 3.43 \\
\hline \multirow[t]{4}{*}{ Left ovary } & length & 110 & 1.99 & 92 & 2.32 & 42 & 2.54 \\
\hline & width & 110 & 1.45 & 92 & 1.71 & 42 & 1.82 \\
\hline & depth & 110 & 0.95 & 92 & 1.19 & 42 & 1.29 \\
\hline & weight & 64 & 1.54 & 48 & 2.52 & 30 & 2.90 \\
\hline
\end{tabular}

ovary. There is a significant increase in the size of the corpus luteum with increasing size of the foetus. This is shown in Fig. 5.

\section{DISCUSSION}

Also in this material the right ovary appears to be a little larger than the left, as shown in Table 1. The difference is small and not statistically significant. It appears that the ovaries of the pregnant goat are larger than those of the non-pregnant animal (Lyngset 1968a), but neither is this difference statistically significant. It was assumed that the ovaries of the pregnant goat would be larger than those of the non-pregnant goat. The reason 
T a ble 3. Diameter and weight of the corpus luteum ( $\mathrm{cm}$ and $\mathrm{g}$ ).

\begin{tabular}{|c|c|c|c|}
\hline & $\begin{array}{l}\text { Corpus } \\
\text { luteum }\end{array}$ & $\begin{array}{l}\text { No. of } \\
\text { observ. }\end{array}$ & Mean \\
\hline $\begin{array}{l}\text { C. 1. in } \\
\text { right ovary }\end{array}$ & $\begin{array}{l}\text { diameter } \\
\text { weight }\end{array}$ & $\begin{array}{r}181 \\
93\end{array}$ & $\begin{array}{l}1.40 \\
0.83\end{array}$ \\
\hline $\begin{array}{l}\text { C. l. in } \\
\text { left ovary }\end{array}$ & $\begin{array}{l}\text { diameter } \\
\text { weight }\end{array}$ & $\begin{array}{r}141 \\
77\end{array}$ & $\begin{array}{l}1.39 \\
0.83\end{array}$ \\
\hline $\begin{array}{l}\text { C. l. in } \\
\text { both ovaries }\end{array}$ & $\begin{array}{l}\text { diameter } \\
\text { weight }\end{array}$ & $\begin{array}{l}322 \\
170\end{array}$ & $\begin{array}{l}1.39 \\
0.83\end{array}$ \\
\hline $\begin{array}{l}\text { One c. l. in } \\
\text { right ovary }\end{array}$ & diameter & 116 & 1.42 \\
\hline $\begin{array}{l}\text { Two c. l. in } \\
\text { right ovary }\end{array}$ & diameter & 64 & 1.33 \\
\hline $\begin{array}{l}\text { One c. l. in } \\
\text { left ovary }\end{array}$ & diameter & 94 & 1.41 \\
\hline $\begin{array}{l}\text { Two c. l. in } \\
\text { left ovary }\end{array}$ & diameter & 45 & 1.33 \\
\hline
\end{tabular}

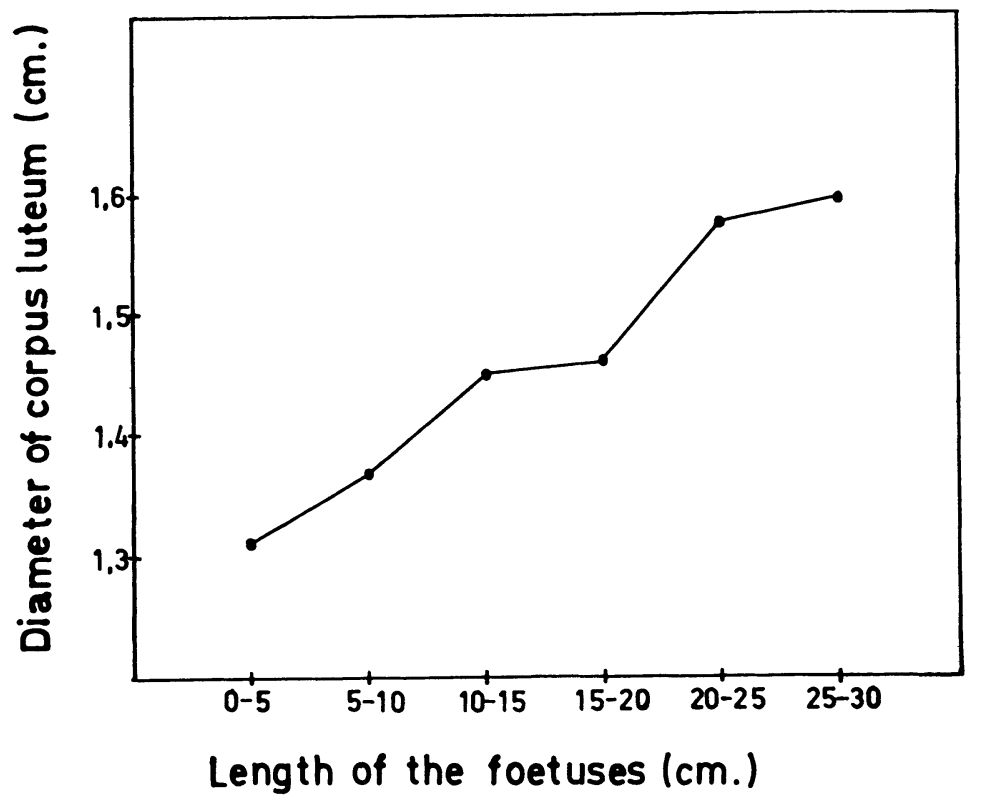

Figur e 5. Variation in size (diameter) of the corpus luteum with increasing size of the foetus. 
for the small difference found here is undoubtedly, as mentioned previously, that slaughtering takes place at the end of the sexual season. Also in the non-pregnant animals most of the ovaries were functionally active and a large number of them contained active corpora lutea and large follicles. It is probable that if organs from goats in anoestrus had been examined, the difference in the size of the ovaries in pregnant and non-pregnant animals would have been more striking.

The caruncles were counted in a number of cases (Table 1), and as previously mentioned it was very difficult to determine the extent to which all of the caruncles took part in the placentation at the stage of pregnancy at which examination took place. The question arised whether all of the caruncles should be counted or only those that were for certain functionally active. In this material all of the visible caruncles were counted. The results show that the whole uterus contains 120-125 caruncles. Martin (1904) reports that the caruncles appear in four rows, as in the cow, and that the whole uterus contains 88-96. Basu et al. (1961) found in their material an average of 51.01 in the left horn and 51.14 in the right one. Altogether these authors found an average of 102 caruncles, and the average number of cotyledons found was 80.47 .

Thus in this material a much larger number of caruncles were found in the uterus than have been reported earlier. Martin does not state whether his report includes only the functionally active caruncles, while apparently Basu et al. have recorded them all.

As expected, the ovaries will increase in size with the increase of the number of corpora lutea present (Table 2). The ovary without corpus luteum in the pregnant animal is smaller than the corresponding ovary in the non-pregnant animal. It may be assumed that pregnant animals have undergone fewer oestrus periods in the sexual season concerned than the non-pregnant animals. From the hypothesis that the size of the ovaries varies with the activity and that they therefore increase slightly in size during the whole sexual season, it is explicable that the ovaries without corpus luteum are larger in the non-pregnant animals than corresponding ones in the pregnant animals.

The size of the corpus luteum is the same whether it is found in the right or the left ovary (Table 3 ). The corpus luteum in non-pregnant animals is smaller than in pregnant ones (Lyngset 
1968a). The organs from the non-pregnant goats were examined at different stages in the cycle and regressive processes were probably in progress in a number of corpora lutea. The difference in size of the corpora lutea in pregnant and non-pregnant animals is not significant.

In this material a statistically significant difference in the size of the corpus luteum has been found depending on whether there are one or more corpora lutea in the same ovary. In cases with two corpora lutea present in the same ovary, they are on the average smaller than when there is only one. The corpus luteum can vary a great deal in size (Fig. 4). A variation in the diameter from 0.30 to $2.70 \mathrm{~cm}$ has been found.

According to Meites et al. (1951) the corpus luteum is necessary to maintain pregnancy in the goat until the 125th day of pregnancy and probably during the whole term. These authors are of the opinion that the production of progesterone in the corpus luteum is greater than the need. They could remove one of two corpora lutea in a twin pregnancy without interrupting the pregnancy. To what degree the remaining corpus luteum hypertrophied after the enucleation of the other one is unknown. The question can be asked to what extent the size of the corpus luteum is dependent upon the secretory activity. In the present material a significant increase in the size (diameter) of the corpus luteum was found with the increasing size of the foetus (Fig. 5). The largest foetuses were almost full term. If the hypothesis that the size of the corpus luteum is dependent upon the activity is correct, this observation should indicate that the corpus luteum is necessary during the whole pregnancy, and that the progesterone production also increases throughout the whole term. The size of the corpus luteum is by no means always connected to the fact whether the progesterone is produced by one or two corpora lutea. In many cases a very small corpus luteum was found $(0.3-0.5 \mathrm{~cm}$ in diameter) even where this was the only one maintaining pregnancy. In most cases where two follicles have ovulated but only one ovum has become fertilized, both corpora lutea will be of the same size and it will be impossible macroscopically to see any difference between them. Neither in these cases was there any difference in the size of the corpus luteum whether it was localized in the ovary on the same side as the foetus or not. It was also impossible to determine from which of the two ova the embryo arised. Because of the great 
tendency to intrauterine migration which is found in the goat (Lyngset $1968 \mathrm{~b}$ ), it cannot be concluded that the embryo necessarily arises from the ovum that was shed from the ovary on the corresponding side.

\section{ACKNOWLEDGMENTS}

The author wishes to thank his colleagues at the slaughterhouses for their help in collecting the material. Thanks are also extended to Professor ö. Nissen, the Agricultural College of Norway, for his valuable help in working up the material. The investigation was financied in part by Niels Thorhaugs Fond.

\section{REFERENCES}

Basu, S., S. K. Goswami \& S. K. De: Studies on the genitalia of she-goat. Indian vet. J. $1961,38,302-304$.

Lyngset, $O$.: Studies on the reproductive organs of the female goat, a preliminary report. Nord. Vet.-Med. 1966, 18, 34-37.

Lyngset, $O$.: Studies on reproduction in the goat. I. The normal genital organs of the non-pregnant goat. Acta vet. scand. 1968a, 9, 208-222.

Lyngset, $O$.: Studies on reproduction in the goat. III. The functional activity of the ovaries of the goat. Acta vet. scand. $1968 \mathrm{~b}, 9$, $268-276$.

Martin, P.: Lehrbuch der Anatomie der Haustiere. Verlag von Schiderhardt-Ebner, Stuttgart 1904.

Meites, J., H. D. Webster, F. W. Young, F. Thorps jr. \& R. N. Hatch: Effects of corpora lutea removal and replacement with progesterone on pregnancy in goats. J. Animal Sci. 1951, 10, 411416.

Richter, J. \& R. Gätze: Tiergeburtshilfe. Paul Parey, Berlin und Hamburg 1960.

Taneja, G. C.: Observation on foetal losses in goat. Indian vet. J. 1959, $36,439-444$.

\section{SUMMARY}

1. A study of a total of 397 pregnant sex organs from goats in various stages of pregnancy was undertaken.

2. The volume of the uterus increases rapidly after conception. Even with one foetus in each uterine horn the uterus will at times be definitely asymmetrical.

3. An uneven distribution of the caruncles in the uterus is often found. The number found averaged $120-125$, with an average of 61.3 and 60.7 caruncles in the right and left uterine horn respectively.

4. In the ovaries, in addition to the corpus luteum of pregnancy, follicles of up to $1 \mathrm{~cm}$ in diameter are often observed. The ovaries increase in size with the number of corpora lutea present.

5. When the ovary contains two corpora lutea these are on the average smaller than when only one corpus luteum is present. A variation 
in the diameter of the corpus luteum from $0.30 \mathrm{~cm}$ to $2.70 \mathrm{~cm}$ was found.

6. A significant increase in the size of the corpus luteum with the increasing size of the foetus was found.

\section{ZUSAMMENFASSUNG \\ Untersuchungen über die Reproduktion bei Ziegen. II. Die Genitalorgane bei trächtigen Ziegen.}

1. Eine Untersuchung von insgesamt 397 trächtigen Geschlechtsorganen von Ziegen bei verschiedenen Stadien in der Trächtigkeit ist vorgenommen worden.

2. Eine Vergrösserung des Uterus tritt kurz nach der Konzeption ein. Auch in Fällen mit einer Frucht in jedem Gebärmutterhorn kann zu Zeiten eine ausgesprochene Asymmetrie von Uterus festgestellt werden.

3. Die Karunkeln im Uterus sind oft ungleich verteilt. Die durchschnittliche Zahl der Karunkeln betrug 120-125, mit durchschnittlich 61,3 im rechten und 60,7 im linken Gebärmutterhorn.

4. In den Ovarien wurden oft ausser Corpus luteum graviditatis Follikeln mit einem Durchmesser biz zu $1 \mathrm{~cm}$ beobachtet. Die Grösse der Ovarien steigt mit der Zahl von Corpora lutea.

5. Wo zwei Corpora lutea im selben Ovarium vorkommen, sind diese im allgemeinen kleiner als in den Fällen, wo sich nur ein Corpus luteum im Ovarien befindet. Die Variation in der Grösse des Corpus luteum schwankte von 0,30 bis $2,70 \mathrm{~cm}$ im Durchmesser.

6. Es ist statistisch gesichert worden, dass die Grösse vom Corpus luteum mit der zunehmenden Grösse der Früchte ansteigt.

\section{SAMMENDRAG}

Undersøkelser over reproduksjonen hos geit.

II. Genitalorganene hos drektige geiter.

1. Det er foretatt en unders $\varnothing$ kelse av ialt 397 drektige kjønnsorganer fra geit på forskjellige stadier i drektigheten.

2. En volumfor $\varnothing$ kning av uterus kommer hurtig etter konsepsjonen. Selv med ett foster $\mathrm{i}$ hvert uterushorn vil det til tider være en uttalt asymmetri av uterus.

3. Det finnes ofte en ujevn distribusjon av karunkler i uterus og det er funnet et gjennomsnittlig antall karunkler på 120-125, med gjennomsnittlig $61.3 \mathrm{i}$ h $\varnothing$ yre og $60.7 \mathrm{i}$ venstre uterushorn.

4. I ovariene er det ved siden av corpus luteum graviditatis ofte iakttatt follikler opptil $1 \mathrm{~cm}$ i diameter. Ovariene vil $\phi \mathrm{ke}$ i st $\varnothing$ rrelse med antall corpora lutea.

5. Når det forekommer to corpora lutea i samme ovarium, er disse i gjennomsnitt mindre, enn når det bare er ett corpus luteum i ovariet. Det er funnet en variasjon i størrelsen i corpus luteum fra $0,30 \mathrm{~cm}$ til $2,70 \mathrm{~cm}$ i diameter.

6. Det er funnet en signifikant $\varnothing \mathrm{kning}$ i st $\varnothing$ rrelsen av corpus luteum med $\varnothing$ kende st $\varnothing$ rrelse av fostrene. 